\title{
Materi Lingkungan dalam Pembelajaran Bahasa Indonesia di Sekolah
}

\author{
Oleh : Ridho Sandra Putra
}

Ridho141925@gmail.com

Masalah lingkungan bukanlah suatu hal yang baru. Masalah lingkungan seperti pembakaran hutan, pencemaran lingkungan, pemburuan binatang dan tumbuhan yang dilindungi merupakan permasalahan yang dari dulunya sudah ada, dan terus berlanjut tanpa ada penyelesaian. Masalah lingkungan ini disebabkan oleh aktivitas manusia yang ceroboh dan intensif di daerah alami untuk meningkatkan kualitas hidup mereka. Kerusakan lingkungan menyebabkan serangkaian masalah dengan alam sumber daya, iklim, polusi, makanan, dan ekonomi, sehingga terjadi ketidakseimbangan dalam lingkungan hidup.

Salah satu upaya penyelesaian masalah lingkungan yang berkelanjutan ini adalah dengan menanamkan sejak dini kepada generasi muda tentang pentingnya menjaga lingkungan. Hal-hal kecil seperti tidak membuang sampah sembarangan, menggunakan air seperlunya, dan lain sebagainya merupakan langkah awal yang bisa dilakukan. Menanamkan rasa tanggung jawab dan kesadaran akan menjaga lingkungan dapat dilakukan di sekolah dengan menerapkan materi lingkungan dalam pembelajaran. Salah satu pembelajaran yang dapat dikaitkan dengan materi lingkungan adalah pembelajaran bahasa. Menurut Uyar dan Ensar (dalam Ramadhan et al, 2019), menggunakan tema lingkungan dalam pembelajaran teks dapat memicu minat siswa dalam mempelajari bahasa dan secara berimplikasi dapat meningkatkan pengetahuan siswa tentang lingkungan hidup.

Pembelajaran berbasis lingkungan bertujuan untuk membuat siswa berpartisipasi dalam melindungi lingkungan. Tidak memandang lingkungan sebagai sesuatu yang bisa dieksploitasi untuk kepentingan pribadi, tetapi sebagai aset berharga yang layak dilindungi untuk kelangsungan hidup manusia. Oleh karena itu, peting untuk mengembangkan pengetahuan tentang lingkungan, kesadaran lingkungan dan perubahan perilaku terhadap lingkungan. Pendidikan lingkungan dapat membantu siswa memikirkan kembali hubungan antara manusia dan lingkungan, memahami lingkungan, menyadari masalah lingkungan dan mempertimbangkan masalah lingkungan yang berkaitan dengan kehidupan (Ramadhan et al, 2019). 
Menurut Obasoro, Oyinloye, dan Ilensami (dalam Ramadhan et al, 2019), siswa perlu memiliki pengalaman dalam mengambil inisiatif sehubungan dengan persyaratan yang mendesak di bidang tantangan global dan masyarakat. Sejalan dengan itu, menurut Bergman B,G (dalam Ramadhan et al, 2019), guru memainkan peran penting dalam mengajarkan pendidikan lingkungan hidup. Guru dapat memberikan materi lingkungan kepada siswa agar siswa dapat memahami contoh yang tepat yang bisa ditemui di sekitarnya. Selain guru, siswa juga memiliki peranan yang penting dalam proses pembelajaran. Karena tanpa adanya respon atau tindakan pengaplikasian materi yang diberikan oleh guru, maka tujuan dari pembelajaran tersebut tidak akan tercapai.

Berdasarkan permasalahan yang dijabarkan di atas, penulis melakukan penelitian mengenai pentingnya materi lingkungan dalam pembelajaran bahasa Indonesia kepada beberapa orang Siswa dan Mahasiswa . Penelitian dilakukan dengan membuat 10 pernyataan dalam bentuk angket google form. Hasil yang didapat dari penelitian ini adalah sebagai berikut. Pernyataan pertama, Materi lingkungan sangat diperlukan dalam mata pelajaran bahasa Indonesia., 73,3 \% menyatakan sangat setuju dan 26,7 \% menyatakan setuju. Pernyataan kedua Menggunakan tema lingkungan dalam pembelajaran teks dapat memicu minat siswa untuk mempelajari bahasa dan berimplikasi meningkatkan pengetahuan siswa tentang lingkungan hidup, 43,3 \% menyatakan sangat setuju, 53,3\% menyatakan setuju, dan 3,4\% menyatakan kurang setuju. Untuk pernyataan ketiga, yaitu, Guru memiliki peran penting dalam mengajarkan pendidikan lingkungan hidup kepada siswa, 46,7 \% menyatakan sangat setuju dan 53,3 \% menyatakan setuju. Pernyataan keempat adalah Guru menyiapkan bahan ajar tentang materi lingkungan.. Pada pernyataan ini, 53,3 \% menyatakan sangat setuju, 43,3 \% menyatakan setuju. Pada pernyataan kelima, yaitu, Dengan mempelajari lingkungan dapat mengembangkan keterampilan siswa dalam menulis teks deskripsi, $60 \%$ menyatakan sangat setuju, 36,7 \% menyatakan setuju, dan 3,3\% menyatakan kurang setuju. Pernyataan keenam adalah Guru menggunakan lingkungan dalam proses pembelajaran. $60 \%$ menyatakan sangat setuju dan $40 \%$ menyatakan setuju. Penyataan ketujuh adalah Guru menanamkan kepada siswa untuk selalu menjaga dan mencintai lingkungan, $60 \%$ menyatakan sangat setuju, $40 \%$ menyatakan setuju. Pernyataan kedelapan 
berbunyi Materi pembelajaran berdasarkan lingkungan lebih mudah disampaikan dari pada teori ilmiah. $70 \%$ menyatakan sangat setuju, 26,7 \% menyatakan setuju, dan 3,3\% menyatakan kurang setuju. Pernyataan kesembilan berbunyi Materi lingkungan lebih memudahkan siswa dalam memamahami materi bahasa Indonesia. Pada pernyataan ini, $50 \%$ menyatakan sangat setuju dan $50 \%$ menyatakan setuju. Pernyataan kesepuluh, yaitu, Sebelum memulai pembelajaran 15 menit awal, guru menugaskan siswa untuk mengamati lingkungan sekitar, kemudian guru meminta siswa untuk menuliskan cerita pendek mengenai lingkungan yang sudah diamati, $50 \%$ menyatakan sangat setuju, 43,3\% menyatakan setuju, dan 6,7 \% menyatakan kurang setuju.

Dari hasil penelitian penulis di atas, dapat disimpulkan bahwa materi lingkungan sangat penting untuk diterapkan dalam pembelajaran bahasa Indonesia. Materi lingkungan memudahkan siswa dalam memamahami materi bahasa Indonesia dengan baik, menambah wawasan siswa, serta dapat membangun kecerdasan ekologis siswa. Materi lingkungan merupakan materi yang sangat erat kaitannya dengan kehidupan sehari-hari. Karena itu, dengan materi lingkungan guru bisa dengan mudah mencari contoh relevan yang membuat siswa lebih paham akan materi yang diberikan, sehingga dapat membantu guru dalam mengimplikasikan materi bahasa Indonesia di sekolah. Hal ini sesuai dengan pendapat Hauchild S, Poltavthenko E, dan Stoller F, L (dalam Ramadhan et al, 2019), dengan mengintegrasikan pendidikan lingkungan ke dalam kelas, guru dapat meningkatkan minat siswa terhadap permasalahan kontemporer yang mungkin langsung mempengaruhi masa depan mereka. 


\section{Daftar Rujukan}

Bergman B G 2016 Assessing impacts of locally designed environmental education projects on students' environmental attitudes, awareness, and intention to act Environmental Education Reseach 22(4) 480-503.

Hauchild S, Poltavthenko E and Stoller F L 2012 Going green: Menging environmental education and language instruction English Teaching Forum Number 2 2-13.

Obasoro C B, Oyinloye O A and Ilensami A A 2013 The importance of environmental education to secondary education level in Akure South local goverment area, Ondo State Nigeria African Research Review 7(4) 298-306.

Ramadhan, S., Sukma, E., \& Indriyani, V. (2019). Environmental education and disaster mitigation through language learning. IOP Conference Series: Earth and Environmental Science, 314, pp. 1-9.

Uyar Y and Ensar F 2016 Does mother tongue education support development of environmental literacy in Turkey? An analysis of Turkish course book International Journal of Environmental \& Science Education 11(1) 1-8. 